Table 5. Pairwise genetic divergence value (percentage) among the Grateloupia species

\begin{tabular}{llllll}
\hline Species & \multicolumn{1}{c}{$G c$} & \multicolumn{1}{c}{$G o$} & \multicolumn{1}{c}{$G f$} & \multicolumn{1}{c}{$G l$} & \multicolumn{1}{c}{$G i$} \\
\hline G. catenata $(G c)$ & $0.0^{\#}$ & $0.004^{* *}$ & $0.009^{* *}$ & $0.004^{* *}$ & $0.004^{* *}$ \\
G. orientalis $(G o)$ & $0.08^{*}$ & $0.0^{\#}$ & $0.001^{* *}$ & $0.001^{* *}$ & $0.002^{* *}$ \\
G. filicina $(G f)$ & $0.08^{*}$ & $0.01^{*}$ & $0.0^{\#}$ & $0.001^{* *}$ & $0.001^{* *}$ \\
G. lithophila $(G l)$ & $0.09^{*}$ & $0.03^{*}$ & $0.01^{*}$ & $0.0^{\#}$ & $0.001^{* *}$ \\
G. indica $(G i)$ & $6.0^{*}$ & $6.3^{*}$ & $6.1^{*}$ & $6.3^{*}$ & $0.0^{\#}$ \\
\hline
\end{tabular}

${ }^{\#}$ Within species distance values. ${ }^{*}$ Between species genetic divergence values. $* *$ Standard deviation values.

One of the invasive species, G. turuturu has been reported to have efficient stress tolerance under adverse environmental conditions and is resistant to hydrogen peroxide, heavy metals, salinity, heat stress and oxidative stress $^{13}$. Accordingly, G. orientalis and G. catenata may also possess high tolerance capacity to biotic and abiotic stress.

The classical taxonomy of $G$. orientalis and G. catenata affirmed that they are different species with some similarities in their morphological features (Table 4). Analysis of morphological data and phylogenetic tree showed that both are closely related species.

In the present study, we characterized $G$. orientalis and $G$. catenata using morphological, anatomical and molecular methods. The study also reports the extended distribution of $G$. orientalis and $G$. catenata in Indian waters and enriches the database of algae from the country. These two species might have entered through shipping activities due to the presence of major ports along the Indian coast. Further studies are required to analyse the population dynamics as well as invasive potential of these species from the Indian coast.

1. Guiry, M. D. and Guiry, G. M., AlgaeBase. World-wide electronic publication. National University of Ireland, Galway, Ireland, 2020; http://www.algaebase.org (accessed on 24 March 2020).

2. Miller, K. A., Hughey, J. R. and Gabrielson, P. W., First report of the Japanese species Grateloupia lanceolata (Halymeniaceae, Rhodophyta) from California, USA. Phycol. Res., 2009, 57, 238241.

3. Montes, M., Rico, J. M., García-Vázquez, E. and Borrell, Y. J., Morphological and molecular methods reveal the Asian alga Grateloupia imbricata (Halymeniaceae) occurs on Cantabrian Sea shores (Bay of Biscay). Phycologia, 2016, 55, 365-370.

4. D'Archino, R., Nelson, W. A. and Zuccarello, G. C., Invasive marine red alga introduced to New Zealand waters: first record of Grateloupia turuturu (Halymeniaceae, Rhodophyta). N. Z. J. Mar. Freshw. Res., 2007, 41, 35-42.

5. Oza, R. M. and Zaidi, S. H., A Revised Checklist of Indian Marine Algae, CSMCRI, Bhavnagar, 2001, p. 296.

6. Kawaguchi, S., Wang, W. H., Horiguchi, T., Sartoni, G. and Masuda, M., A comparative study of the red algae Grateloupia fillicina (Halymeniaceae) from the Northwestern Pacific and Mediterranean with the description of Grateloupia asiatica, sp. nov. J. Phycol., 2001, 7, 433-442.

7. Azevedo, C. A. A. D., Cassano, V., Júnior, P. A. H., Batista, M. B. and de Oliveira, M. C., Detecting the non-native Grateloupia turuturu (Halymeniales, Rhodophyta) in southern Brazil. Phycologia, 2015, 54, 451-454.
8. Lee, J. I., Kim, H. G., Geraldino, P. J. L., Hwang, I. K. and Boo, S. M., Molecular classification of the genus Grateloupia (Halymeniaceae, Rhodophyta) in Korea. Algae, 2009, 24, 231-238.

9. Doyle, J. J., Isolation of plant DNA from fresh tissue. Focus, 1990, 12, 13-15.

10. Lin, S. M., Liang, H. Y. and Hommersand, M. H., Two types of auxiliary cell ampullae in Grateloupia (Halymeniaceae, Rhodophyta), including G. taiwanensis sp. nov. and G. orientalis sp. nov. from taiwan based on $\mathrm{rbcl}$ gene sequence analysis and cystocarp development. J. Phycol., 2008, 44, 196-214.

11. Clerck, O. D., Gavio, B., Fredericq, S., Barbara, I. and Coppejans, E., Systematics of Grateloupia filicina (Halymeniaceae, Rhodophyta), based on $\mathrm{Rbcl}$ sequence analyses and morphological evidence, including the reinstatement of $G$. minima and the description of G. capensis sp. nov. J. Phycol., 2005, 41, 391-410.

12. Yu, L., Wang, H. and Luan, R., Grateloupia tenuis Wang et Luan sp. nov. (Halymeniaceae, Rhodophyta): a new species from South China sea based on morphological observation and $r b c L$ gene sequence analysis. Biomed. Res. Int., 2013; https://doi.org/10. $1155 / 2013 / 560163$.

13. Liu, F. and Pang, S. J., Stress tolerance and antioxidant enzymatic activities in the metabolisms of the reactive oxygen species in two intertidal red algae Grateloupia turuturu and Palmaria palmata. J. Exp. Mar. Biol. Ecol., 2010, 382, 82-87.

14. Wang, H. W., Kawaguchi, S., Horiguchi, T. and Masuda, M., Reinstatement of Grateloupia catenata (Rhodophyta, Halymeniaceae) on the basis of morphology and $r b c L$ sequences. Phycologia, 2000, 39, 228-237.

ACKNOWLEDGEMENTS. We thank the Director, ICAR-Central Institute of Fisheries Education, Mumbai for providing the necessary facilities and funds to carry out this work. The first author thanks Indian Council of Agricultural Research, New Delhi for JRF fellowship.

Received 20 November 2019; revised accepted 9 July 2020

doi: $10.18520 / \mathrm{cs} / \mathrm{v} 119 / \mathrm{i} 5 / 849-854$

\section{Securing the livelihood of small and marginal farmers by diversifying farming systems}

\section{Bussa Bhargavi ${ }^{1}$ and Umakanta Behera ${ }^{2, *}$}

${ }^{1}$ Division of Agronomy, Indian Council of Agricultural Research, Central Institute for Cotton Research, Nagpur 440 010, India ${ }^{2}$ College of Agriculture, Central Agricultural University, Kyrdemkulai, Umiam 793 103, India

Mono-cropping of rice-wheat system in the IndoGangetic Plains (IGP) has resulted in natural resource degradation, decline in farm profitability, factor productivity and environmental security. Contrary to mono-cropping, biodiversity is considered as an index to agricultural sustainability. Accordingly, an integrated farming system (IFS) model involving land-based enterprises - crops, dairy, fishery, duckery, poultry, biogas plant and agroforestry was developed in 1 ha area at the ICAR-Indian Agricultural Research

*For correspondence. (e-mail: ukb2008@gmail.com) 
Institute (IARI), New Delhi during 2015-16 to 201718. The objective of the present study was to find an alternative approach to replace rice-wheat system and enhance farmer's income in a sustainable manner. The IFS model had the potential to improve farmers' livelihood with a variety of produce, on-farm resource recycling and enhancing their income to INR 378,784 as against INR 68,200 from the rice-wheat system. The waste and by-products of one enterprise served as an input for the other, and reliance on off-farm inputs was reduced to a great extent aiding in strengthening environmental sustainability.

Keywords: Integrated farming system, livelihood security, resource recycling, small and marginal farmers, sustainability.

INDIAN agriculture is predominantly small-farm agriculture. The average size of an operational holding in the country had dropped to 1.08 ha in 2015-16 from 1.15 ha in 2010-11 Agriculture Census ${ }^{1}$. Out of 145.72 million land holders in India, $68 \%$ are marginal farmers who own less than 1 ha and $18 \%$ are small farmers owning between 1 and 2 ha. Small and marginal farmers constitute $86 \%$ of the total farming community.

The monoculture practice and disciplinary approach is unable to meet the growing and changing food demand, and improve the livelihood of smallholders on a sustainable basis ${ }^{2}$. Crop diversification towards high-value crops and resource-use-efficient approaches like integrated farming systems (IFS) are often advocated now as prominent sources of growth in farmers' income on a sustainable basis ${ }^{3}$. Multi-enterprise farming plays a vital role in making the farming system sustainable through different cropping, biodiversity and ecosystem services.

Inclusion of high-value crops like vegetables, flowers and fodder crops will improve the economic condition of small and marginal farmers owing to higher price and/or higher volume of their main and by-products ${ }^{4}$. Hence, efforts are needed to promote diversification of ricebased cropping sequence in the country with high-value crops for sustaining the productivity and to meet the demand for vegetables, pulses and oilseeds. IFS modules developed in different parts of the country, including dairy, duckery, poultry, horticulture, apiary and fishery have been found to increase profit compared to cropping alone. Hence, selection of components needs to be carefully planned to harvest the synergism among them towards efficient utilization of the resource base and to increase overall system productivity. With the view to find an alternative to the rice-wheat mono-cropping of IGP, an IFS model has been designed in this study, in the context of small and marginal farmers, to evaluate its performance and potential to double the farm income.

A study was conducted on IFS at Indian Council of Agricultural Research-Indian Agricultural Research Institute (ICAR-IARI), New Delhi, during 2015-16 to 2017-
18, involving crops (maize, pea, mustard, green gram, cotton, wheat, bottle gourd, onion and okra), dairy, fishery, duckery, poultry, biogas plant, fruit trees and agroforestry.

The climate of the study area is semi-arid with dry, hot summers and cold winters and average annual rainfall of $1088 \mathrm{~mm}$. Soil available nitrogen was measured using the method of Subbiah and Asija ${ }^{5}$. Soil available phosphorus was determined following the method of Olsen et al. ${ }^{6}$. Soil available potassium was measured according to Jackson ${ }^{7}$. Soil organic carbon was determined using the method of Walkley and Black ${ }^{8}$. Soil $\mathrm{pH}$ was determined using Beckman's pH meter. Soil of the experimental field was sandy clay loam in texture, slightly alkaline in reaction ( $\mathrm{pH} 6.9)$, low in organic carbon $(0.38 \%)$, available $\mathrm{N}$ $\left(251.8 \mathrm{~kg} \mathrm{ha}^{-1}\right)$, available $\mathrm{P}\left(11.2 \mathrm{~kg} \mathrm{ha}^{-1}\right)$ and medium in $\mathrm{K}\left(254 \mathrm{~kg} \mathrm{ha}^{-1}\right)$.

Five cropping systems, i.e. maize-pea-okra, maizemustard-green gram, cotton-wheat, bottle gourd-onion and okra-wheat were evaluated in 0.625 ha area with four replications in randomized block design for economic performance in order to fit into the model.

Table 1 provides details of variety used, seed rate, fertilizer dose and spacing. N, P and $\mathrm{K}$ were applied through urea, di-ammonium phosphate and muriate of potash respectively. In maize, half dose of $\mathrm{N}$ and full doses of $\mathrm{P}$ and $\mathrm{K}$ were applied during sowing, while the remaining $\mathrm{N}$ was applied one month after sowing. In cotton, half dose of $\mathrm{N}$ and full doses of $\mathrm{P}$ and $\mathrm{K}$ were applied at the time of sowing and the rest applied equally at flowering and boll development stage. Full doses of N, P and K were applied while sowing in case of bottle gourd. One-third of N, P and $\mathrm{K}$ does were applied at sowing and the remaining as two splits at 4 and 8 weeks after sowing in okra. All the crops were harvested manually at physiological maturity stage. Economic and biological yields were recorded for all the crops. After harvesting of kharif crops, rabi and summer crops were sown in the same plots without disturbing the layout according to recommended package of practices (Table 1). In wheat, half dose of $\mathrm{N}$ and full doses of $\mathrm{P}$ and $\mathrm{K}$ were applied during sowing, while the remaining $\mathrm{N}$ was top-dressed before the first irrigation. Half dose of $\mathrm{N}$ and full doses of $\mathrm{P}$ and $\mathrm{K}$ were applied at the time of sowing of mustard and the remaining half dose of $\mathrm{N}$ was applied after one month.

In onion, one-third dose of $\mathrm{N}$ and full doses of $\mathrm{P}$ and $\mathrm{K}$ were applied with last field operation. The remaining two-thirds of $\mathrm{N}$ was applied equally at 30 and 60 days after transplanting. Green gram was harvested at physiological stage of maturity, while 5-6 pickings of okra were harvested in its green and immature stage.

Economic yields of the component crops were converted to wheat equivalent yield (WEY), taking into account the prevailing minimum support price/market prices of the crops ${ }^{9}$. System productivity was calculated by adding WEY of the component crops. 


\section{RESEARCH COMMUNICATIONS}

Table 1. Production technology adopted for raising crops during 2015-16 and 2016-17

\begin{tabular}{|c|c|c|c|c|c|}
\hline Cropping system & Maize-pea-okra & Maize-mustard-green gram & Cotton-wheat & Bottle gourd-onion & Okra-wheat \\
\hline \multicolumn{6}{|l|}{ Variety } \\
\hline Kharif & PMH-1 & PMH-1 & Shriram-6588 (BG-II) & PSPL & Arka Anamika \\
\hline Summer & Arka Anamika & SML-668 & - & - & - \\
\hline \multicolumn{6}{|l|}{ Seed rate $(\mathrm{kg} / \mathrm{ha})$} \\
\hline Kharif & 20 & 20 & 3 & 3 & 15 \\
\hline Summer & 15 & 20 & - & - & - \\
\hline \multicolumn{6}{|l|}{ Spacing $(\mathrm{cm} \times \mathrm{cm})$} \\
\hline Kharif & $60 \times 15$ & $60 \times 15$ & $75 \times 50$ & $250 \times 100$ & $60 \times 50$ \\
\hline$R a b i$ & $40 \times 10$ & $50 \times 10$ & $20 \times 10$ & $25 \times 10$ & $20 \times 10$ \\
\hline Summer & $60 \times 50$ & $30 \times 10$ & - & - & - \\
\hline \multicolumn{6}{|c|}{ Fertilizer $(\mathrm{kg} / \mathrm{ha})\left(\mathrm{N}: \mathrm{P}_{2} \mathrm{O}_{5}: \mathrm{K}_{2} \mathrm{O}\right)$} \\
\hline Kharif & $120: 60: 40$ & $120: 60: 40$ & $120: 60: 60$ & $60: 40: 50$ & $60: 30: 30$ \\
\hline Summer & $70: 40: 40$ & $20: 40: 30$ & - & - & - \\
\hline
\end{tabular}

WEY of maize $=\frac{\text { Maize yield }(\mathrm{kg}) \times \text { Maize price }(\mathrm{INR})}{\text { Wheat price }(\mathrm{INR})}$

The other components of IFS, viz. dairy unit with three crossbred cows (two HF cows and one Jersey) were maintained. A biogas unit of $2 \mathrm{~m}^{3}$ capacity was established beside the dairy. The fishery unit consisted of four species of fish in the fish pond ( $0.1 \mathrm{ha})$, viz. catla (Catla catla), rohu (Labeo rohita), mrigal (Cirrhinus mrigala) and Chinese carp (Ctenopharyngodon idella) in the ratio of $3: 4: 3: 2$ (fingerlings@12,000 nos/ha). Fifty local breed poultry birds of Aseel-12, Kadaknath - 14, Ankleswar - 12, Nikobari - 12 were maintained in a poultry shed constructed on the fish pond. Ducks (35 birds of Khakhi Campbell breed) were maintained in a shed constructed separately over the fish pond dyke and allowed to range in the pond during daytime. An area of 0.1 ha was allotted for fruit production (lemon, kinnow, guava, banana and jamun). The entire 1.0 ha area was surrounded by iron mesh fence. Country bean (Lablab purpureus) and poi saag (Basella rubra) were sown along the fence and allowed to grow on it. The by-products of one component were effectively exploited in another component, but cost of the by-product was included in the cost structure of each component.

Economic yields of all components of IFS were also converted to WEY, taking into account the prevailing market prices of the products ${ }^{10}$.

For example,

$$
\text { WEY of dairy }=\frac{\text { Milk yield }(\mathrm{l}) \times \text { Milk price }(\text { INR })}{\text { Wheat price }(\text { INR })} \text {. }
$$

In this study an effort has been made for a holistic integration of different land-based enterprises, viz. crop, dairy, fishery, duckery, poultry, biogas, agroforestry and fruit production, by considering small farmers with the objectives of achieving sufficiency in food, increased income and employment opportunity for the farm families and recycling of farm waste and by-products.

Among the five cropping systems, each in $1250 \mathrm{~m}^{2}$ (Table 2), the cost of cultivation was higher in the maizepea-okra cropping system (INR 16,840) followed by bottle gourd-onion system (INR 15,420). Prasad et al. ${ }^{11}$ also concluded that the cost of vegetables cultivation is higher due to more fertilization and human labour. Higher net returns were earned from the bottle gourd-onion system and it fetched an additional income of INR 11,212, 19,266, 16,390 and 11,309 over the maize-pea-okra, maize-mustard-green gram, cotton-wheat and okra-wheat systems respectively. The lowest net returns of INR 11,456 were for the maize-mustard-green gram system.

Table 3 gives the cost structure of different components of IFS.

The total expenditure incurred in a year to maintain the dairy unit was INR 330,482, of which feed had the major share accounting for $51.7 \%$. Feed cost was calculated based on feed requirement of a cow, i.e. green fodder $16 \mathrm{~kg} \mathrm{cow}^{-1} @$ INR $5 \mathrm{~kg}^{-1}$; dry fodder $-5 \mathrm{~kg} \mathrm{cow}^{-1} @$ INR $12 \mathrm{~kg}^{-1}$ and concentrated feed $-2 \mathrm{~kg} \mathrm{cow}^{-1} @$ INR $14 \mathrm{~kg}^{-1}$. Labour cost contributed $23.58 \%$ and fixed cost was $12.47 \%$ of total expenditure. Gross returns from the dairy unit were INR 492,120, which included the amounts for 11,553 litres of milk (INR 462,120) and manure (INR $30,000)$. The net income obtained was INR 161,638. The income per day on cost basis was INR 449.

A biogas unit was established beside the dairy unit in the experiment field. The amount of biogas produced was estimated on a monthly basis round the year. The maximum biogas production of $0.577 \mathrm{~m}^{3}$ was in July, while it was minimum in January $\left(0.3 \mathrm{~m}^{3}\right)$. Even though the volume of gas produced during winter was comparatively less, it suffices the kitchen needs of a small family with two adults and three children. 
RESEARCH COMMUNICATIONS

Table 2. Economics of cropping systems in the integrated farming system (IFS) model

\begin{tabular}{lccc}
\hline Cropping system & Cost of cultivation (INR) & Net income (INR) & Benefit : cost ratio \\
\hline $\mathrm{CS}_{1}$ : Maize-pea-okra & 16,840 & 19,063 & 2.13 \\
$\mathrm{CS}_{2}$ : Maize-mustard-green gram & 11,456 & 11,009 & 1.96 \\
$\mathrm{CS}_{3}$ : Cotton-wheat & 13,660 & 13,885 & 2.02 \\
$\mathrm{CS}_{4}$ : Bottle gourd-onion & 15,420 & 30,275 & 2.96 \\
$\mathrm{CS}_{5}$ : Okra-wheat & 14,780 & 18,966 & 2.28 \\
Total & 72,156 & 93,198 & 2.29 \\
\hline
\end{tabular}

Table 3. Economics of different components of the IFS model

\begin{tabular}{|c|c|c|c|c|c|c|c|}
\hline \multirow[b]{2}{*}{ Enterprise } & \multicolumn{2}{|c|}{ Expenditure (INR) } & \multirow[b]{2}{*}{$\begin{array}{c}\text { Total expenditure } \\
\text { (INR) }\end{array}$} & \multicolumn{2}{|c|}{ Income (INR) } & \multirow[b]{2}{*}{$\begin{array}{l}\text { Gross income } \\
\text { (INR) }\end{array}$} & \multirow[b]{2}{*}{$\begin{array}{l}\text { Net income } \\
\left(\text { INR day }{ }^{-1}\right)\end{array}$} \\
\hline & $\begin{array}{l}\text { Fixed } \\
\text { cost }\end{array}$ & $\begin{array}{l}\text { Variable } \\
\text { cost }\end{array}$ & & $\begin{array}{l}\text { Main } \\
\text { product }\end{array}$ & By-product & & \\
\hline Dairy & 57,098 & 273,384 & 330,482 & 462,120 & 30,000 & 492,120 & 449 \\
\hline Fishery & 15,400 & 38,392 & 53,792 & 91,080 & - & 91,080 & 84 \\
\hline Duckery & 12,610 & 18,069 & 30,679 & 50,590 & 10,500 & 61,090 & 104 \\
\hline Poultry & 4,390 & 24,388 & 28,778 & 28,050 & 25,000 & 53,050 & 80 \\
\hline Fruit production & 2,958 & 5,700 & 8,658 & 19,900 & - & 19,900 & 31 \\
\hline Agroforestry & 231 & 1,100 & 1,331 & 4,560 & - & 4,560 & \\
\hline Biogas & 4,000 & - & 4,000 & 5,000 & 4,000 & 9,000 & 9 \\
\hline Fence crop - country bean & & 2,000 & 2,000 & 10,000 & - & 10,000 & 14 \\
\hline
\end{tabular}

From the fishery unit gross and net returns of INR 91,080 and 37,288 were achieved with an expenditure of INR 53,792. The total fish biomass production was $759 \mathrm{~kg}$ from 0.1 ha area of the pond.

Duckery unit yielded a gross income of INR 61,090 by rearing 35 ducks of 'Khaki Campbell' variety, with an expenditure of INR 30,679. A total of 5059 eggs were produced from 12,168 duck days in a year, with an average egg production of $41.6 \%$ of the total duck days.

The poultry unit was started with 50 birds of Aseel 12, Kadaknath - 14, Ankleswar-12, Nikobari - 12 over the fish pond. A total of 2805 eggs were produced within 11 months from 13,046 hen days with an average egg production of $21.5 \%$ of the total hen days. From poultry, gross income of INR 53,050 was attained with an expenditure of INR 28,778.

Gross and net returns of INR 19,900 and INR 11,242 were achieved with 35-40 kinnow plants along the boundary.

Twenty-five moringa trees (Moringa oleifera) provided a gross income of INR 4560 and net income of INR 3229.

Fence crops like country bean and climbing spinach (Basella rubra) were allowed to grow on the fence. The gross income from these crops was INR 10,000 with an expenditure of INR 2000.

Table 4 and Figure 1 reveal that the contribution of cropping, dairy, fishery, duckery, poultry, fruit production, fence crops, biogas and agroforestry to net returns was $24.6 \%, 42.7 \%, 9.8 \%, 8.0 \%, 7.6 \%, 3.0 \%, 2.1 \%, 1.3 \%$ and $0.9 \%$ respectively. Dairy component in IFS led to maximum net returns of INR 161,638 followed by cropping system with INR 93,198. Net income obtained from all the components was INR 378,784, which was four times higher than the rice-wheat system ${ }^{12}$. Unlike conventional rice-wheat system, the IFS model generated employment of 628 man days ha ${ }^{-1}$ that helped in engaging two labourers throughout the year. This assured employment also helped reduce migration of agricultural labourers to adjacent towns. The model also attracted many rural youth to adopt IFS as an entrepreneurship venture.

The cost of cultivation in the present study was higher in the maize-pea-okra cropping system followed by the bottle gourd-onion system. To realize higher returns from vegetable crops, farmers have to spend more on seeds, fertilizers, labour, irrigation and harvesting. Reddy ${ }^{13}$ also reported that the total cost per hectare was higher in highvalue crops (vegetables, fruits and flowers). The higher net income of INR 30,275 was realized from the bottle gourd-onion system. Inclusion of vegetables (bottle gourd and onion) in the system, besides improving the system productivity, fetched good market price and thereby increased the net returns. Besides, raising of vegetable crops (onion) during summer season is economically remunerative, as the supply of vegetables from rainfed areas is drastically reduced and vegetable prices are much higher. Therefore, surplus onions produced can be transported to areas of high demand even 2-3 months after harvesting, as they have a good shelf-life. The lowest net income of INR 11,456 was noticed with the maize-mustard-green gram system. This was due to lower yields from mustard and green gram. Crop production provides a range of residues that can be utilized by dairy animals. These include cereal straw (viz. wheat and 


\section{RESEARCH COMMUNICATIONS}

Table 4. Productivity (wheat equivalent yield), and profitability and employment generation of different components of IFS (pooled data of three years)

\begin{tabular}{|c|c|c|c|c|c|}
\hline Enterprise & Area (ha) & 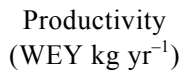 & $\begin{array}{l}\text { Cost of cultivation } \\
\text { (INR) }\end{array}$ & $\begin{array}{l}\text { Net income } \\
\text { (INR) }\end{array}$ & $\begin{array}{l}\text { Employment generation } \\
\text { (man days) }\end{array}$ \\
\hline Cropping system & 0.625 & 10,335 & 72,156 & 93,198 & 150 \\
\hline Dairy & 3 cows & 30,758 & 330,482 & 161,638 & 365 \\
\hline Duckery & 35 birds & 3,818 & 30,679 & 30,411 & 26 \\
\hline Fishery & 0.1 & 5,693 & 53,792 & 37,288 & 26 \\
\hline Poultry & 50 birds & 3,316 & 24,272 & 28,778 & 26 \\
\hline Fruit production (kinnow + lemon) & 0.05 & 1,244 & 8,658 & 11,242 & 15 \\
\hline Agroforestry & 0.012 & 285 & 1,331 & 3,229 & 3 \\
\hline Biogas & $\operatorname{KVIC}\left(2 \mathrm{~m}^{3}\right)$ & 563 & 4,000 & 5,000 & 12 \\
\hline \multirow[t]{2}{*}{ Country bean } & Fencing area & 625 & 2,000 & 8,000 & 5 \\
\hline & & & 527,370 & 378,784 & 628 \\
\hline Rice-wheat & 1 & 9,860 & 78,630 & 68,200 & 148 \\
\hline
\end{tabular}

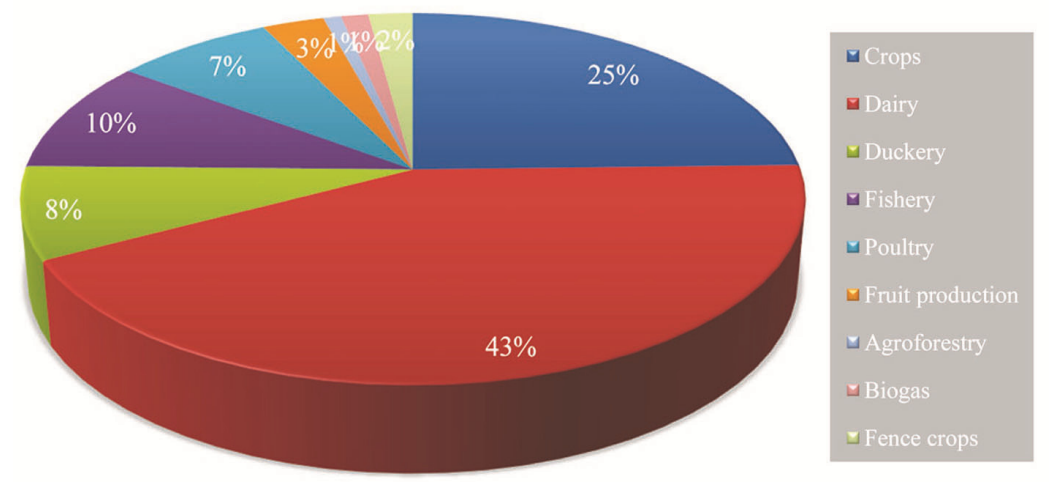

Figure 1. Contribution of different integrated farming system components to net returns.

maize) and grain legume haulms (viz. green gram and pea). Animal-crop interactions besides providing positive and economic benefits, also promote sustainable agriculture and environmental protection. The benefits are directly associated with increased productivity, increased income and improved sustainability ${ }^{14-16}$.

The dairy unit provided considerable amount of protein and fat, thus helping to meet the balanced nutritional needs of resource poor farmers and also provided valuable manure to cropping thereby bringing down fertilizer cost, which is one of the expensive inputs to small farmers for crop production. These results are in accordance with the findings of Parthasarathy and Hall ${ }^{17}$. The manure generated from the dairy unit with three crossbred cows was nearly $18 \mathrm{t} \mathrm{yr}^{-1}\left(50-54 \mathrm{~kg} \mathrm{day}^{-1}\right)$. Out of this, nearly 25-30 kg was used in the biogas unit for biogas production. About $5 \mathrm{t}$ of biogas slurry was produced from the biogas unit. The slurry was found to be rich in many essential elements, including $\mathrm{N}, \mathrm{P} \mathrm{K}$ and trace elements with higher manurial value than compost and FYM. Khan et al. ${ }^{18}$ reported that fertilizer dose with $50 \%$ each of biogas slurry and chemical fertilizer gave the highest baby corn yield. Slurry was applied to crops, fruit trees and the fish pond.

Pisciculture apart from supplying excellent quality fish protein to the farm families, also generated employment of 26 man days. These results are in conformity with the findings of Behera and Mahapatra ${ }^{19}$. Poultry droppings of about $0.6 \mathrm{t}$ helped in encouraging plankton growth, which is essential for fish production. It is clear that a small farmer who integrates duckery and poultry with fishery earns an attractive amount of profit and can boost his income. Duckery and poultry supply a good balanced and nutritious food like egg/meat for a decent living.

Fruit trees at the boundary can help as a live fence and shelterbelt, apart from supplying the family members with nutritious fruits. Agroforestry unit with moringa serves as a good source of iron, which is essential for the human body.

The major objective of this study was to enhance the income of farmers by integrating different land-based enterprises, and reduce production cost by recycling farm by-products and waste within the system. A close examination of resource recycling indicated the interdependence of different components of the farming system to make the farmer self-sufficient in terms of balanced diet for leading a healthy life and also making farms selfsufficient through recycling of by-products/waste (Figure 2 ). The by-products of crops like wheat straw, maize stover, legume straw and other crop residues served as feed for dairy animals. Litter from the cowshed and weeds was utilized for compost-making and the valuable 


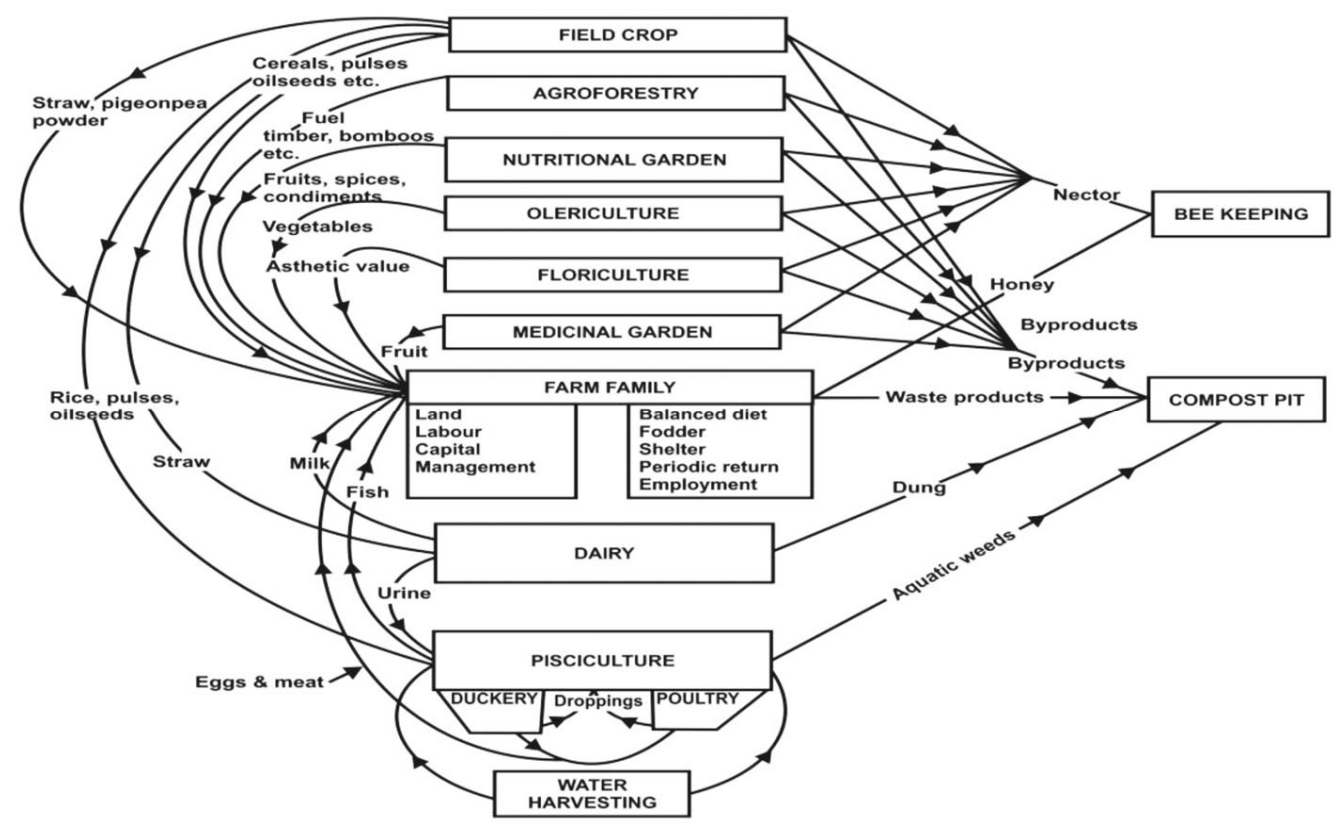

Figure 2. Resource flow in the IFS model at the research farm in ICAR-IARI, New Delhi.

compost utilized in the cultivation of vegetables, fruits and other crops, thus bringing down fertilizer cost. The by-product of dairy, i.e. cow dung, was a major raw material for biogas. Digested slurry of biogas formed a major part of feed of pisciculture for increasing plankton growth as well as supplying valuable manure to increase crop productivity. The by-product of poultry and duckery, i.e. droppings, formed an important ingredient of pisciculture for increasing plankton growth. Fruits, fence crops and moringa provided diversified nutritious food, thus ensuring nutritional security of the farm families.

This study clearly indicate that the rice-wheat cropping system can be suitably diversified with bottle gourdonion, maize-pea-okra, cotton-wheat and okra-wheat cropping systems under small holder farming for higher productivity and net returns. The IFS model involving different land-based enterprises generated a net income of INR 378,784, which was about four times higher and employment of 628 man days was three times higher than the conventional rice-wheat system, it also provided a potential alternative to the rice-wheat system and helped double farmer's income. The by-products/waste of one component in the system served as an input for another, which reduced the reliance on off-farm inputs aiding in strengthening sustainability. The IFS model accommodated a number of crops and enterprises and produced many commodities round the year, which helped in better family nutrition and biodiversity conservation. Such a multi-enterprise model also attracted the rural youth to adopt it as a self-employment vocation.

1. Anon., Agriculture Census. Department of Agriculture, Cooperation and Farmers' Welfare, Ministry of Agriculture and Farmers' Welfare, Government of India, 2016, p. 10.
2. Mahapatra, I. C. and Behera, U. K., Rice-based farming systems for livelihood improvement of Indian farmers. Indian J. Agron., $2011, \mathbf{5 6}(1), 1-19$

3. Chand, R., Doubling farmers income: rationale, strategy, prospects and action plan. NITI Policy Paper No. 1/2017, NITI Aayog, GoI, 2017, p. 20.

4. Dass, A., Sudhishri, S., Patnaik, U. S. and Lenka, N. K., Effect of agronomic management on watershed productivity, impact indices, crop diversification and soil fertility in Eastern Ghats of Orissa. J. Soil Water Conserv., 2009, 8(3), 34-42.

5. Subbiah, B. V. and Asija, G. L., A rapid procedure for estimation of available nitrogen in soils. Curr. Sci., 1956, 25, 259260.

6. Olsen, S. R., Cole, C. V., Watanabe, F. S. and Dean, L. A., Estimation of available phosphorus in soils by extraction with sodium bicarbonate. USDA Circular, 1954, 939, 19, Washington DC, USA.

7. Jackson, M. L., Soil Chemical Analysis, Prentice Hall of India Pvt Ltd, New Delhi, 1973.

8. Walkley, A. J. and Black, I. A., An examination of the Degtjareff method for determination of soil organic matter and a proposed modification of the chronic acid titration method. Soil Sci., 1934, 37, 29-38.

9. Bhargavi, B., Behera, U. K., Rana, K. S. and Singh, R., Productivity, resource-use efficiency and profitability of high-value crops embedded diversified cropping systems. Indian J. Agric. Sci., 2019, 89(5), 821-827.

10. Channabasavanna, A. S., Biradar, D. P., Prabhudev, K. N. and Mahabhaleswar, H., Development of profitable integrated farming system model for small and medium farmers of Tungabhadra project area of Karnataka. Karnataka J. Agric. Sci., 2009, 22(1), $25-27$.

11. Prasad, D., Yadava, M. S. and Singh, C. S., Diversification of rice (Oryza sativa)-based cropping systems for higher productivity, profitability and resource-use efficiency under irrigated ecosystem of Jharkhand. Indian J. Agron., 2013, 58(2), 77-83.

12. Shah, M. S., Verma, N. and Vishwkarma, S. K., Diversification of rice (Oryza sativa)-based cropping systems for higher production efficiency, water productivity and economic viability in Madhya Pradesh. Indian J. Agron., 2015, 60(1), 25-30. 
13. Reddy, A., Profitability and labour use in cropping systems Indian J. Dryland Agric. Res. Dev., 2014, 29(1), 97-106.

14. Pant, J., Demaine, H. and Edwards, P., Bio-resource flow in integrated agriculture-aquaculture systems in a tropical monsoonal climate: a case study in northwest Thailand. Agric. Syst., 2005, 83, 203-219.

15. Shekinah, D. E., Jayanthi, C. and Sankaran, N., Physical indicators of sustainability - a farming systems approach for the small farmer in the rain-fed vertisols of western zone of Tamil Nadu. J. Sustain. Agric., 2005, 25, 43-65.

16. Devendra, C., Animal production and rainfed agriculture in Asia: potential opportunities for productivity enhancement. Outlook Agric., 2000, 29(3), 161-175.

17. Parthasarathy, R. P. and Hall, A. J., Importance of crop residues in crop-livestock systems in India and farmers' perceptions of fodder quality in coarse cereals. Field Crops Res., 2003, 84, 189-198.

18. Khan, S. A., Malav, L. C., Kumar, S., Malav, K. and Gupta, N., Resource utilization of biogas slurry for better yield and nutritional quality of baby corn. Adv. Environ. Agric. Sci., 2016, 382-394.

19. Behera, U. K. and Mahapatra, I. C., Income and employment generation for small and marginal farmers through integrated farming systems. Indian J. Agron., 1999, 44(3), 431-439.

ACKNOWLEDGEMENTS. We acknowledge the Division of Agronomy, ICAR-IARI, New Delhi for providing support for the study under the project 'Sustainable Integrated Farming Systems for Livelihood Security of Small and Marginal Farmers'.

\section{Isolation and characterization of indigenous nucleopolyhedrovirus infecting fall armyworm, Spodoptera frugiperda (J.E. Smith) (Lepidoptera: Noctuidae) in India}

\author{
G. Sivakumar ${ }^{1, *}$, M. Kannan ${ }^{2}$, S. Ramesh Babu ${ }^{3}$, \\ M. Mohan ${ }^{1}$, M. Sampath Kumar', \\ P. Raveendran', T. Venkatesan ${ }^{1}$, \\ R. Rangeshwaran ${ }^{1}$, Chandish R. Ballal ${ }^{1}$ and \\ P. Ram Kumar ${ }^{1}$ \\ ${ }^{1}$ ICAR-National Bureau of Agricultural Insect Resources, Hebbal, \\ Bengaluru 560 024, India \\ ${ }^{2}$ Department of Plant Protection, Horticultural College and Research \\ Institute, Periyakulam, Tamil Nadu Agricultural University, \\ Coimbatore 641 003, India \\ ${ }^{3}$ Agricultural Research Station, Borwat Farm, MPUAT, \\ Banswara 327 001, India
}

Fall armyworm (FAW), Spodoptera frugiperda (J.E. Smith) (Lepidoptera: Noctuidae) is an invasive insect pest of maize in India. Natural occurrence of nucleopolyhedrovirus (NPV) infection on $S$. frugiperda

\footnotetext{
*For correspondence. (e-mail: sivakumarg.nbaii@gmail.com)
}

larvae was recorded in 2018 during surveys conducted in maize fields in Chikkaballapura district of Karnataka, and Coimbatore and Tirupattur districts of Tamil Nadu. A strain of $S$. frugiperda nucleopolyhedrovirus (SpfrNPV NBAIR1) infecting $S$. frugiperda was isolated from the diseased larvae; morphological and biological characteristics were studied. Electron microscopic studies showed tetrahedral-shaped SpfrNPV occlusion bodies (OBs) of size $1.64 \mu \mathrm{m}$. Dose-mortality bioassays revealed that first, second and third instar larvae were equally susceptible $\left(\mathrm{LC}_{50}\right.$ 3.71-5.02 OBs $/ \mathrm{mm}^{2}$ ) to SpfrNPV infection. A PCR technique for detection of viral DNA in $S$. frugiperda NPV was developed by employing the polyhedrin gene (polh)-specific primers. The amplicon of $618 \mathrm{bp}$ was amplified, sequenced and NCBI GenBank accession number was obtained (MT422725). Blast analysis revealed that SpfrNPV conserved polh gene sequence matched $100 \%$ with the reference GenBank sequence (J04333) from the NCBI database which confirmed the identity of the SpfrNPV.

Keywords: Insect pests, maize, nucleopolyhedrovirus, Spodoptera frugiperda.

MAIZE is an important cereal crop cultivated in India after rice and wheat and is valued as food, feed, fodder and industrial raw material. India is the major maize producer and contributes $2 \%$ of the world's production ${ }^{1}$. The fall armyworm (FAW), Spodoptera frugiperda (J.E. Smith) (Lepidoptera: Noctuidae) has been reported as a devastating invasive insect pest of maize in America and Africa. Spodoptera frugiperda invaded India during May 2018 and then moved onto the neighbouring countries ${ }^{2}$. The pest is now reported in Yemen, Bangladesh, Sri Lanka, Thailand, Myanmar, China, Indonesia, Laos, Malaysia, Vietnam, Republic of Korea and Japan within a short span of time ${ }^{3}$. It has now established in India and causes extensive damage on maize throughout the country. The outbreak of $S$. frugiperda in India is of serious concern because of the favourable weather conditions and availability of maize throughout the year. Maximum incidence $(62.5 \%)$ of the pest was reported from Hassan district, Karnataka ${ }^{4}$. Advisories have been issued by the Government of India for its management through the use of biopesticides and chemical insecticides to avoid extensive damage on maize (http://ppqs.gov.in). Fall armyworm feeds on above-ground parts of maize, especially on the leaf whorl of young plants, which are up to 45 days old. Larvae are voracious feeders and can destroy the whole plant in a short time ${ }^{5}$. Studies in Africa indicated that infestation of $S$. frugiperda on maize exceeds $94 \%$ with damage levels ranging between $25 \%$ and $50 \%$ (ref. 6).

The development of multi-insecticide resistance and resistance against transgenic $B t$ maize makes $S$. frugiperda a challenging insect pest to manage using chemical insecticides and Bt toxins. Spodoptera frugiperda nucleopolyhedrovirus (SpfrNPV) belongs to the Baculoviridae 